\title{
Changing dietary habits among Akwen Xerente
}

\author{
Mudanças dos hábitos alimentares entre os Akwen Xerente \\ Cambiar los hábitos alimenticios entre Akwen Xerente.
}

Tatiana Evangelista da Silva Rocha ${ }^{1}$, Reijane Pinheiro da Silva ${ }^{2}$, Maira Messias do Nascimento ${ }^{3}$

${ }^{1,2,3}$ Universidade Federal do Tocantins, Palmas, TO, Brazil.

\section{ABSTRACT}

The research aimed to identify the current feed of Xerente people in Indian villages Porteira and Funil in the city of Tocantinia / TO. It was used a qualitative ethnographic approach. Conducted from September 2013 to August 2014. The data were presented in a diary, through participant observation of food practices with the guidance of a script. A process of dietary change that permeates the culture of this people is taking place. Factors such as the deficit in the planting gardens, the recent arrival of energy, and therefore the technology has allowed access to processed foods. But some families still maintain the farming of cassava, yam, and beans. The main animals that are hunted in the village are peccary, deer and armadillo. It was possible to point which foods are inserted in the Xerente feed and factors related to this situation.

DESCRIPTORS

Indian Food, Dietary Change, Processed Foods. 


\section{INTRODUCTION}

The diet reveals origins, civility, behaviors, cultures, beliefs, spiritual or material values transmitted collectively that are characteristic of a society. The Brazilian diet has African, indigenous and white European inheritance ${ }^{(1)}$.

The eating habits of a population are connected to their customs, education and way of life. In all civilizations, eating is more than just surviving, but a cultural and symbolic act that represents a way of life, deepens family and social relationships, and enriches the knowledge construction process $^{(2)}$. Traditional foods also have symbolic representation related to cosmology, body formation, exchanges, reciprocities, rites, among others, differentiated according to each group ${ }^{(3)}$.

Culinary is a way to evaluate the culture of a population, and a language that must be known to better understand their customs. Classical studies on anthropology of diet consider the food act not only as biological and aimed at meeting nutritional needs, but as a means of studying people's culture because it that allows to absorb cognitive and symbolic aspects. For indigenous people, food is culture and part of cultural and oral tradition that is not spoken, but practiced and related to $\operatorname{cosmolog} y^{(4)}$.

The First National Survey of Health and Nutrition of Indigenous People conducted between 2008 and 2009 has identified the most consumed foods by the Brazilian population, namely: rice (84.0\%), coffee (79.0\%), beans (72.8\%), salty bread (63.0\%) and beef (48.7\%). The consumption of juices and refreshment drinks (39.8\%) and soft drinks (23.0\%) also stood out, as well as the low presence of fruits $(16.0 \%)$ and vegetables $(16.0 \%)^{(7)}$.

The traditional food of indigenous people in the Akwẽ/ Xerente region is cassava, the base of their diet, consumed mainly in the form of grolado (a type of porridge made with manioc bread), manioc bread and flour. Game meat is in second place of importance, followed by the consumption of fish and fruits of the cerrado. However, their current diet is basically composed of rice, which may be accompanied by fish, game meat, beef and puba flour ${ }^{(4)}$.

These data were confirmed in the First National Survey of Health and Nutrition of Indigenous People, which showed cassava representing $96.6 \%$ of the main products grown in gardens or plantations on indigenous lands in the northern region. The survey also showed that $96.7 \%$ of the indigenous people of the northern region evaluated in the study hunt and fish to eat, and $91.7 \%$ collect food to eat ${ }^{(8)}$.

It is noteworthy that the Akwẽ's people diet also includes several native fruits such as mango, pequi, mangaba and buriti, complemented with cultivation gardens where they plant cassava, yam, potato, banana, sugarcane, water yam, andu beans, fava beans, corn, rice and pumpkin. The animals that serve as food are monkeys, coatis, agoutis, seriemas, emus, anteaters, tapir, armadillos, wild ducks and ducks ${ }^{(9)}$.

Therefore, the cerrado is a means of subsistence for the Akwẽ people, in addition to fishing, although these resources are compromised due to intense fires and the impact of the construction of the Luís Eduardo Magalhães hydroelectric plant $t^{(4)}$. Among the factors that may cause changes in the diet of indigenous people are the approximation with the non-indigenous society, access to welfare policies that sometimes do not consider traditional practices and consequently, end up changing the traditional diet of these people $^{(3)}$.

Studies on indigenous eating habits indicate the increased consumption of animal fat and sugar and decreased intake of cereals, legumes, fruits and vegetables in this population. These influences observed in the studies also showed increased body mass index $\left(>25.00 \mathrm{~kg} / \mathrm{m}^{2}\right)$ and attributed these alterations to dietary changes, with lower consumption of traditional foods in opposition to a higher intake of industrialized food. As a result, chronic non-communicable diseases (NCDs) such as high blood pressure (hypertension), diabetes mellitus (DM) and obesity have grown and reached significant and worrying levels for a population that had no such concern $^{(8)}$.

The First National Survey of Health and Nutrition of Indigenous People showed the Brazilian government priorities of reducing inequities in all aspects, with attention to health and that the knowledge about the health, nutrition and food state of indigenous people in Brazil still require further studies, because those already existent are quite superficial $^{(8)}$.

According to the survey mentioned above ${ }^{(8)}$, it was observed that the food consumption of indigenous people is going through a change process with direct impact on their health and culture, resulting in increased risk of chronic diseases. Therefore, the present study aimed to observe the changes in the current diet of Xerente people in the indigenous villages of Porteira and Funil, located in the municipality of Tocantínia, state of Tocantins (TO).

\section{METHOD}

This is a research of qualitative ethnographic approach, conducted between September 2013 and August 2014. The Porteira village has approximately 350 indigenous people and the Funil village has about 161 indigenous people, and these locations were chosen for their proximity to the city ${ }^{(5-6)}$. This type of research allows incorporating cultural aspects that are particular of the study object. According to Minayo ${ }^{(10)}$, the qualitative methodology allows the understanding of social relations because it addresses a universe of meanings, reasons, aspirations, beliefs, values and attitudes of the study object, working with a reality that cannot be quantified and delves deeper into the worlds of meanings of human actions and relations.

The findings of qualitative methodology are not a result of any procedures or forms of quantification. This method enables an understanding of the symbolic and particular universe of the experiences, behaviors, emotions and feelings experienced, or even the understanding of cultural phenomena and interactions between people, their social groups and institutions ${ }^{(11)}$.

While carrying out this work, the researcher was in the 
field of study to ensure a relationship of trust between her and the object of study, breaking a situation of 'superiority' by approaching and knowing the symbolic and subjective world of the object of study. For the proper development of qualitative research, the researcher had to engage with the field and the subjects of the study, aiming to understand the specific processes of that reality ${ }^{(11)}$.

Ethnography refers to the social research that has particular characteristics. People's behavior was studied in their natural context and data were collected through observation $^{(12)}$.

The most important ethical elements in a study are the transparency regarding the work procedures and endorsement of the studied community. The caciques (native Chiefs) gave statements demonstrating their interest in beginning the research in the villages. After their approval were taken the first steps to contribute with health improvements of the Akwẽ Xerente people.

Since this is a study of qualitative ethnographic approach, data were collected through participant observation of the eating practices that were described in a field diary.

Participant observation is a process in which the researcher is just an observer of a social situation to carry out a scientific investigation, know and understand the reality $^{(13-14)}$. The researcher-observer is directly related to its object of research in the social space of the research, and participates of the social life as much as possible, aiming to obtain data and understand the research context. Therefore, the observers are part of the context under their observation and, without doubt, modify it because of their interference, in the same way that they are personally modified.

A structured script containing information about the most commonly consumed traditional and processed foods and the appliances used was developed to guide the observation, with reference in the booklets of the First National Survey of Health and Nutrition of Indigenous People ${ }^{(8)}$.

\section{RESULTS AND DISCUSSIONS}

From visits to the field of study, it became clear that the diet of these indigenous people is going through a change process together with transformations taking place in their culture. This fact was noted by the presence of industrialized food packaging in the whole village.

However, some factors have brought access to processed and unprocessed food products available in the markets, namely: the deficit in the planting of the gardens given the autonomy reached in the market by selling handcrafts on the square, employment, governmental and projects benefits, livestock presence that sometimes destroys the fields, the electricity that brought technology, the demarcation of land, among others.

In the visits, it was observed that traditional physical activities are no longer being practiced. Young people do not want to practice the traditional corrida de tora (log races) for their increased interest in playing football, which is not a traditional practice.

The food practices of the Akwẽ Xerente people cannot be defined according to a model of industrial society yet, because the data found by the First National Survey of Health and Nutrition of Indigenous People and the observations made during visits confirm that they still use natural resources as a means of survival and maintenance of culture. However, during the field observations in the villages, were found many types of industrialized foods that are surely changing their eating habits such as juice powders, instant noodles, soybean oil, margarine, packets of sweet biscuits, and chocolate powder.

According to the observations by Silva and Oliveira ${ }^{(15)}$, in educational settings, there is still a generic concept of 'being a native indigenous', superficially translated in an image of naked and painted people residing in indigenous community houses and not developing productive activities. Opposed to this ethnocentric vision, the authors understand that indigenous people consciously make use of technological artifacts different from their culture. In the past, these people used to communicate through signs of the nature and nowadays they communicate through amateur radios present in most Xerente villages. They also have telephone or mobile phone facilities and internet.

With the recent arrival of electricity, the houses have antennas and televisions, among other domestic appliances such as refrigerators, stereos, DVD players, blenders, and stoves, although the wood stove was still used in some cases. The same was observed by Rodrigues ${ }^{(16)}$ in the Salto village: 'Brick houses, parabolic antennas in almost all of them, electricity'.

The existing conflict between livestock and maintaining plantation gardens was observed in visits to the study field and described by Schmidt ${ }^{(4)}$ as something still present, with few families keeping food crops such as cassava and yam. Raising cattle is difficult because creation is loose and the creators are unable to build fences given their poor financial conditions. Such impasse has led to changes in dietary practices. Handcraft is also very present in these areas, with confection of products using raw materials such as golden grass, seeds, feathers, and babaçu straw, which are sold in the city or at special events, helping with the family income, together with the Bolsa Familia social benefit received by all families. According to Schmidt ${ }^{(4)}$, referring to the Salto village: the making and trade of handcrafts with golden grass has been one of the main economic activities that generate income. Basketry, bows and arrows and necklaces are also traded in the region. Many pieces of this handcraft are made with raw material extracted from the cerrado and still available: golden grass, buriti fiber, talquezal grass seeds (capim navalha), coconut straw, among others.

The food practices were found to be a matter of concern in those villages because of the emergence of diseases as diabetes mellitus, hypertension and childhood malnutrition. The Xerente people consider that their eating habits are compromised and one of the factors causing this problem is the demarcation of their land, which is getting smaller. However, some families still keep the cultivation of cassava, yams and andu beans. Moreover, according to reports from residents, the main animals hunted are collared peccary, deer and armadillo. During the field observation 
it was possible to visit a house that had prepared for lunch a turtle caught in the village. The fishing of turtles is also a feature of the subsistence regime of Javaé people in the island of Bananal-Tocantins ${ }^{(17)}$.

The houses of both studied villages have similar structures, made of adobe (the adobe brick is made of clay that is taken from the soil and baked in the sun) and covered with straw palm. Two small houses are built in each land; a house is for the bedrooms and living room, and the other is for the kitchen. The bathroom is also built in the yard outside the house, with water tanks, lavatory for hands, shower and toilet. The land around the houses is large, clean and surrounded by trees, mostly of native cerrado fruits such as cashew, mango, pequi, babaçu coconut, and macaúba. In his study conducted in the Salto village, $\mathrm{Schmidt}^{(4)}$ found similar houses. In the villages of Xerente people, 'The bathroom is outside the house, just as the kitchen sink and the laundry area. The backyards have several medicinal and ornamental plants, fruit trees and are cleaned up to a certain point'.

There is also rearing of some animals such as chicken, turkeys, ducks and pigs. According to reports from residents, the majority of animals are for sale and normally not intended for consumption of the farmers and their families.

An important finding during visits to villages was the presence of solid waste scattered around the village, showing the diet changes of the Xerente indigenous communities. Packages of juice powders, filled biscuits, sweet biscuits, crackers, instant noodles, sodas, seasoning mixes, corn flour, canned corn, powdered milk, oil cans, canned sardines, margarine, cachaça (Brazilian spirits) and beer were found, among others.

Schmidt ${ }^{(4)}$ points out that the trash increase in the Salto village is considered a concern for teachers and local residents, who develop environmental activities in an attempt to solve or alleviate the problem. The author explains this factor with the money circulation in the village, and the association of employees and benefit receivers with the capitalist system, since many of them shop in the markets of Tocantínia.

\section{CONCLUSION}

The consumption of processed foods was observed in the studied villages. The proximity to the non-indigenous society and access to processed foods has influenced the eating habits of these people.

A partnership between governmental support and the civil organization is necessary to change the scenery found. However, it is critical to consider the autonomy of the Akwẽ Xerente people and respect the participation of all involved in this process for the success of any activity elaborated for indigenous people.

Several factors must be considered when discussing the eating habits of a society. Moreover, further studies are also necessary given the broadness of this working field.

\section{RESUMO}

A pesquisa objetivou identificar a alimentação atual do povo Xerente, nas aldeias indígenas Porteira e Funil, no município de Tocantínia / TO. Utilizou-se uma abordagem etnográfica qualitativa. Realizada entre setembro de 2013 a agosto de 2014. Os dados foram descritos através de um diário de campo, por meio da observação das práticas alimentares com a orientação de um roteiro. Está ocorrendo um processo de mudança alimentar na cultura deste povo. Fatores como o déficit no plantio das roças, a chegada da energia, e consequentemente a tecnologia, permitiu o acesso a alimentos industrializados. Mas algumas famílias ainda mantem o cultivo de mandioca, inhame, feijão andu. Os principais animais que são caçados na aldeia são caititu, veado e tatu. Foi possível encontrar a presença de alimentos industrializados inseridos na alimentação do Xerente e isso tem provocado alterações nos hábitos desse povo.

\section{DESCRITORES}

Alimentação Indígena, Mudança Alimentar, Alimentos Industrializados.

\section{RESUMEN}

La investigacion tuvo como objetivo identificar los vinculos actuales de los indios Xerente en las aldeas indias Porteira y Funil en el municipio de Tocantinia / TO . Se utilizo un enfoque cualitativo etnografico. Llevado a cabo entre septiembre de 2013 y agosto de 2014. Los datos fueron presentados em un diario, a traves de la observacion participante de las practicas de los alimentos con la guia de un guion. Esta llevando a cabo un proceso de cambio en la dieta que impregna la cultura de este pueblo. Factores como el deficit de la plantacion de los jardines, la llegada de la energia, y por lo tanto la tecnologia ha permitido el acceso a los alimentos procesados. Pero algunas familias aun mantienen los yuca, name, frijoles de paloma. Los principales animales que se cazan en el pueblo son pecari, venado y armadillo. Fue posible senalar los alimentos que se inseriran en el poder de Xerente y los factores relacionados con esta situacion.

DESCRIPTORES

Comida Índia, Cambio en la Dieta, los Alimentos Procesados.

\section{REFERENCES}

1. Araujo WMC, Botelho RA, Ginani VC, Araujo HMC, Zandonani RP. Da alimentação a gastronomia. Brasília: UNB; 2005. 102p.

2. Barreto RLP. Passaporte para o sabor: tecnologias para a elaboração de cardápios. 6a ed. São Paulo: Senac; 2005. p. 11-12.

3. Silva SMO da. Alimentos, Restrições e Reciprocidade no Ritual Xavante do Waptemnhono (Terra Indigena Maraiwatsede, Mato Grosso) [dissertação]. Brasília (DF): Universidade de Brasília, Centro de Desenvolvimento Sustentável; 2013. p.19. 
4. SCHMIDT, R. "Nossa cultura e pequi, frutinha do mato": um estudo sobre as praticas alimentares do povo akwe [dissertação]. Goiânia (GO): Universidade Federal de Goiás, Faculdade de Ciências Sociais; 2011. 128p.

5. Ministério da Saúde. Secretaria Especial de Saúde Indígena. Departamento de Gestão da Saúde Indígena. Dados populacionais de 2013 das etnias cadastradas no SIASI por Distrito Sanitário Especial DSEI [Internet], 2013 [acesso em agosto de 2014]; Disponível em: http:// dw.saude.gov.br.

6. Ministério da Saúde. Secretaria Especial de Saúde Indígena. Distrito Sanitário Especial Indígena de Palmas. Palestra referente ao DSEI Palmas - Sistema de Informações de Saúde Indígena - SIASI. Palmas, TO; 2013.

7. Souza A, Pereira R., Yokoo E., Levy R., Sichieri R. Alimentos mais consumidos no Brasil: Inquérito Nacional de Alimentação $2008-2009$. Rev.Saúde Pública. 2013:47 (1):190S-199S.

8. Brasil. Ministério do Desenvolvimento Social. I Inquérito Nacional de Saúde e Nutrição dos Povos Indígenas. Rio de Janeiro, RJ: MDS; 2009. [acesso 01 Fev2014] Disponível em: http://www.abrasco.org.br/grupos/arquivos/2013-01-23\%2013:44:23.pdf.

9. Lunardi EA. O Xerente: direito, vida e resistência [tese]. Goiânia (GO): Universidade Federal de Goias/Faculdade de direito/Programa de pós-graduação em direito agrário; 1997. 323 f.

10. Minayo MCdeS. Ciência, técnica, arte: o desafio da pesquisa social. In: Minayo MCdeS, Deslandes SF. Pesquisa social: teoria, método e criatividade. 3a ed. Petrópolis: Vozes; 1994. cap. 1. p. 9-29.

11. Medeiros M. Pesquisa de abordagem qualitativa. Rev.Eletr.Enf. 2012: 14 (2): 224-225.

12. Gualda DMR, organizadora. Etnografia. Abordagens teórico-metodológicas qualitativas: a vivencia da mulher no período reprodutivo. Rio de Janeiro (Guanabara): Koogan; 2003. p.19-29.

13. Minayo MCde, organizadora. Trabalho de Campo: contexto de observação, interação e descoberta. In: Pesquisa social: teoria, método e criatividade. Petrópolis: Vozes; 2002. cap.3. p. 61-77.

14. Victoria CG, Knath DR, Hassen MNA, organizadores. Técnicas de pesquisa. Pesquisa qualitativa em saúde: uma introdução ao tema. Porto Alegre: Tomo Editorial; 2000. p.61-78.

15. Silva AA, Oliveira Sde. Os índios e a tecnologia: uma relação de ressignificacao possivel. In: Albuquerque Fede, Almeida SAde organizadora. Educação Escolar Indígena e Diversidade Cultural. 1a ed. Goiânia: PUC Goiás; 2012. p. 330-344.

16. Rodrigues KS. Saúde reprodutiva das mulheres akwe-xerente: uma perspectiva intercultural [dissertação]. Goiânia (GO): Universidade Federal de Goiás, Faculdade de Ciências Sociais. Programa de pós-graduação em antropologia social; 2014. p. 27, 35-47.

17. Mattos M., Mattos P., Croniello M., Araújo E. O povo indígena Javaé da ilha do bananal - TO: uma analise sobre o desenvolvimento dessas comunidades. Rev.Cereus. 2013:5(3):101-116. 